
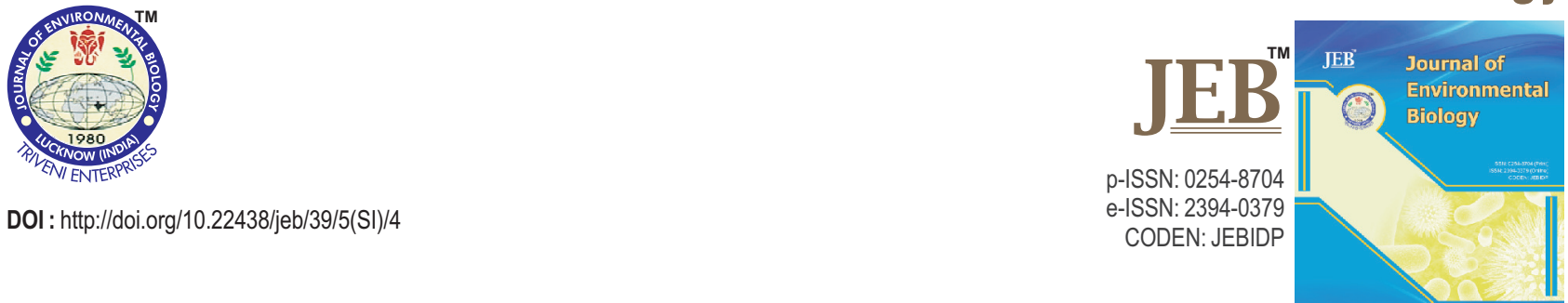

\title{
High ammonia tolerance on growth rate of marine microalga Chlorella vulgaris
}

\section{Authors Info}

M. Goto ${ }^{1}$, N. Nagao ${ }^{2 *}$, F. Md. Yusoff ${ }^{2}$, M.S. Kamarudin ${ }^{3}$, T. Katayama N. Kurosawa', M. Koyama ${ }^{5}$, K. Nakasaki ${ }^{5}$ and T. Toda ${ }^{1}$

${ }^{1}$ Faculty of Science and Engineering, Soka University, Hachioji, Tokyo 192-8577, Japan

${ }^{2}$ Laboratory of Marine Biotechnology, Institute of Bioscience, Universiti Putra Malaysia, 43400 UPM Serdang, Selangor Daryl Ehsan, Malaysia

${ }^{3}$ Department of Aquaculture, Faculty of Agriculture, Universiti Putra Malaysia, 43400 UPM Serdang, Selangor Daryl Ehsan, Malaysia

${ }^{4}$ Graduate School of Agricultural and Life Sciences, The University of Tokyo, Bunkyo, Tokyo 113-8657, Japan

${ }^{5}$ Department of Transdisciplinary Science and Engineering, School of Environment and Society, Tokyo Institute of Technology, Meguro, Tokyo 152-8550, Japan

${ }^{*}$ Corresponding Author Email : norionagao@gmail.com

Key words

Ammonia tolerance

Chlorella vulgaris

Free ammonia

Marine microalga

Productivity

\section{Publication Info}

Paper received : 09.06.2017

Revised received : 15.08 .2017

Re-revised received : 19.11.2017

Accepted : 28.12.2017

\begin{abstract}
Aim: In order to evaluate the effects of ammonia on microalgae growth, Chlorella vulgaris was cultivated in ammonium nitrogen.
\end{abstract}

Methodology: The marine microalgae, Chlorella vulgaris was cultivated in algal media containing increasing concentrations of ammonium concentrations at $320,640,960,1600 \mathrm{mg} \mathrm{l}^{-1}$, with free ammonia concentrations of 0.64 to $2.97 \mathrm{mM}$ and pH ranging from 7.78 to 7.82 . An addition ammonia treatment was $1600 \mathrm{mg} \mathrm{l}^{-1}$ that had a free ammonia concentration of $13.30 \mathrm{mM}$, while a control was $\mathrm{NaNO}_{3}$ at $100 \mathrm{mg} \mathrm{l}^{-1}$.

Results: C. vulgaris grew faster when cultured using ammonium nitrogen than nitrate nitrogen. The dry

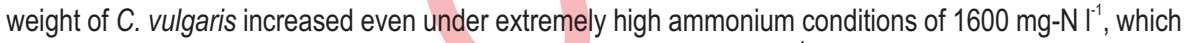
initially contained $2.97 \mathrm{mM}$ free ammonia and reached around $4 \mathrm{~g}$-ds $\mathrm{l}^{-1}$. Algal growth was inhibited in the beginning of the experiment at the highest initial free ammonia concentration of $13.30 \mathrm{mM}$. However, the cell density increased 2 days later when free ammonia concentration decreased to $3.7 \mathrm{mM}$ due to decrease in $\mathrm{pH}$ from 8.48 to 7.88 , and the maximum area productivity of $21.12 \mathrm{~g}-\mathrm{ds} \mathrm{m}^{-2} \mathrm{~d}^{-1}$ was observed.

Interpretation: These results showed that $C$. vulgaris could maintain high productivity even in high free ammonia concentrations of $3.7 \mathrm{mM}$. Because of the high tolerance for free ammonia compared with other microalgae, $C$. vulgaris can be used for the aquaculture industry by removing ammonia from wastewater, and thus improving the water quality.

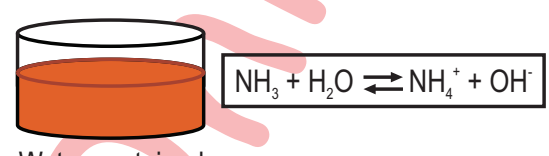

Water contained high ammonium conc.
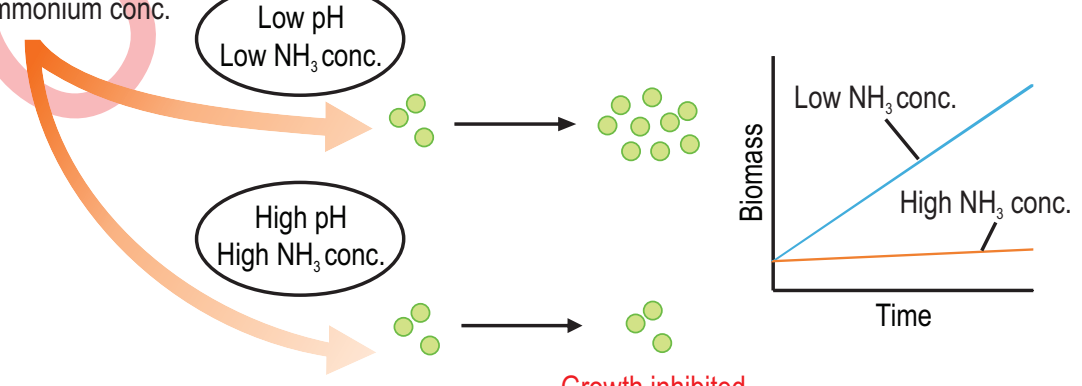

Growth inhibited 


\section{Introduction}

Global warming has become a serious concern of the international community, and it is urgent to reduce the emissions of the greenhouse gases. Microalgae have faster growth rates than terrestrial plants, such as sugar cane or corn (Rodolfi et al., 2009), and thus are able to fix carbon dioxide more efficiently. Moreover, it is possible to culture microalgae on non-arable land such as desert or sea surfaces throughout the year and not compete with agricultural crops. Thereore the cultivation of microalgae is considered to be an effective strategy for reducing greenhouse gas emissions.

When culturing microalgae, it is essential to supply elements for algal growth such as macronutrients, water, carbon dioxide, nitrogen and phosphate, and trace metals such as potassium, iron, manganese and magnesium. Therefore, securing inexpensive nutritional sources is an important issue in order to reduce algal production cost. In case of producing a large amount of microalgae, such as for energy crops, food and feed production, securing inexpensive nitrogen source i.e., major nutrient is especially important. For this reason, many researches use nitrogen in wastewater from sewage and anaerobic digestion (Sialve et al., 2009; Sepúlveda et al., 2015).

Wastewater contains a large amount of nitrogen and phosphorus, which can be potentially used to produce high valueadded products inexpensively in addition to reducing the environmental burdens (Yuan et al., 2011). However, most nitrogen in wastewater exists as ammonia nitrogen which causes the inhibition of algal growth, and its concentration varies from 10 $100 \mathrm{mg}^{-\mathrm{Nl}^{-1}}$ in urban or agricultural effluent to over $2000 \mathrm{mg}^{-\mathrm{Nl}^{-1}}$ in anaerobically digested effluent (de la Noüe et al., 1992; Cai et al., 2013). Free ammonia seriously inhibits algal growth compared to ammonium ions due to the uncoupling effect of free ammonia on photosynthetic processes in isolated chloroplasts (Crofts, 1966). While most strains assimilate all types of nitrogen after transforming to ammonium ion in the cells (Perez-Garcia et al., 2011), this intracellular reaction requires a large amount of energy. Thus, if microalgae can directly use ammonia at the level that does not cause inhibition, ammonia can be the optimal nitrogen source for microalgae by not consuming excessive intracellular energy. Therefore, it is necessary to clarify the free ammonia tolerance of microalgae for economical microalgae cultivation.

From the importance of algal production using nutrition in wastewater, some researchers have investigated the production of microalgae using diluted wastewater. However, few studies have evaluated the impact of free ammonia concentration to the algal production. Azov and Goldman (1982) reported that the growth of marine strains Phaeodactylum tricornutum and Dunaliella tertiolecta, while freshwater strain Scenedesmus obliquus showed $95 \%$ inhibition at $2 \mathrm{mM}$ free ammonia concentration regardless of species. Ammonia concentrations in wastewater from human activities vary widely, from low concentrations of $10-100 \mathrm{mg}^{-\mathrm{Nl}^{-1}}$ in urban or agricultural effluent (de la Noüe et al., 1992) to high concentrations of $2000 \mathrm{mg}^{-\mathrm{Nl}^{-1}}$ or more in anaerobically digested effluent (Cai et al., 2013). Since free ammonia concentrations exceed $2 \mathrm{mM}$ at $\mathrm{pH} 9$, even

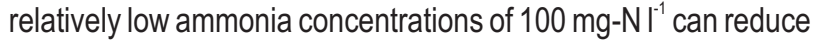
the efficiency of algal growth, and subsequently ammonia removal. In order to achieve both economical microalgae cultivation and ammonia removal, it is necessary to select microalgae that have a high ammonia tolerance, which can be accomplished by evaluating the inhibition level of microalgae at increasing levels of free ammonia.

The aim of this experiment was to determine the effects of increasing free ammonia concentrations on the growth of marine microalga Chlorella vulgaris, which is an important species in the aquaculture industry such as being used to feed and enrich rotifers as live feeds for various fish and crustacean species.

\section{Materials and Methods}

Algal strain and culture medium : Marine microalga Chlorella vulgaris UMT-M1 isolated from Malaysian coastal seawater was obtained from marine microalgae stock culture in Universiti Putra Malaysia. C. vulgaris UMT-M1 cells were grown in the modified Walne's medium (Walne, 1970) in natural seawater filtered with a Whatman GF/F filter. The composition of modified Walne's medium was (per liter): $606.7 \mathrm{mg} \mathrm{NaNO}, 100 \mathrm{mg}$ $\mathrm{NaH}_{2} \mathrm{PO}_{4} \cdot 2 \mathrm{H}_{2} \mathrm{O}, 225 \mathrm{mg} \mathrm{Na}$ EDTA, $168 \mathrm{mg} \mathrm{H}_{3} \mathrm{BO}_{3}, 6.5 \mathrm{mg}$ $\mathrm{FeCl}_{3} \cdot 6 \mathrm{H}_{2} \mathrm{O}, 1.8 \mathrm{mg} \mathrm{MnCl} \cdot 4 \mathrm{H}_{2} \mathrm{O}, 0.5 \mathrm{ml}$ of micronutrient solution and $0.5 \mathrm{ml}$ of vitamin solution. The micronutrient solution

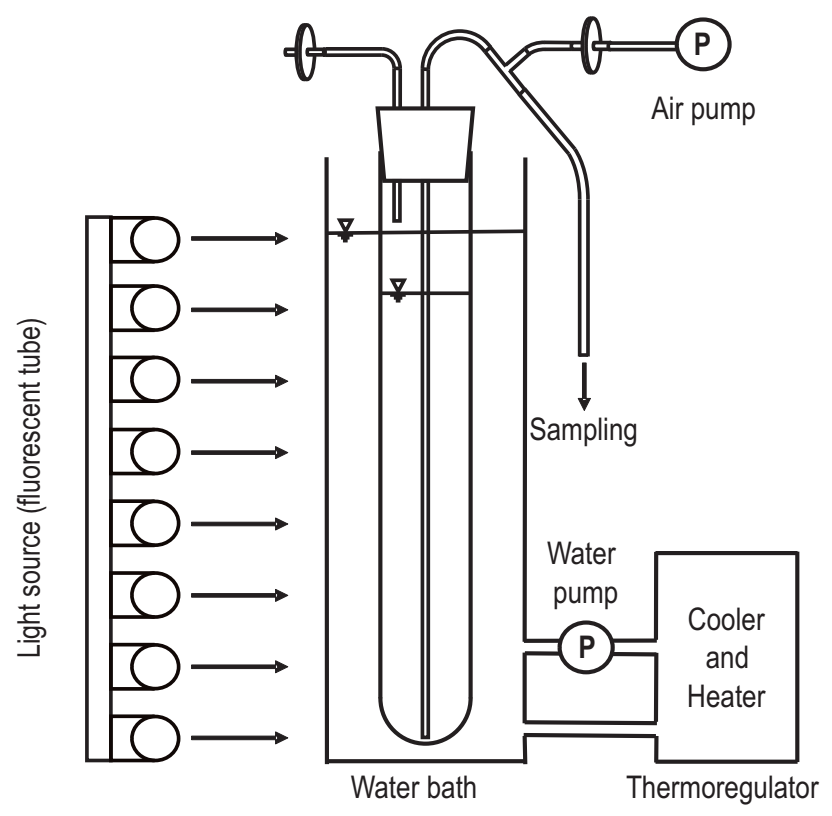

Fig. 1 : Schematic diagram of photobioreactor used in this study 
Table 1 : Initial conditions of nitrogen sources and pH of the culture media used for the cultivation of Chlorella vulgaris.

\begin{tabular}{lllll}
\hline Run & Nitrogen source & Nitrogen concentration $\left(\mathbf{m g}-\mathbf{N I}^{-1}\right)$ & Calculated free ammonia concentration (mM) & $\mathrm{pH}$ \\
\hline Control & $\mathrm{NaNO}_{3}$ & 100 & 0.00 & 7.99 \\
1 & $\mathrm{NH}_{4} \mathrm{Cl}$ & 320 & 0.64 & 7.82 \\
2 & $\mathrm{NH}_{4} \mathrm{Cl}$ & 640 & 1.28 & 7.82 \\
3 & $\mathrm{NH}_{4} \mathrm{Cl}$ & 960 & 1.80 & 7.79 \\
4 & $\mathrm{NH}_{4} \mathrm{Cl}$ & 1600 & 2.97 & 7.78 \\
5 & $\mathrm{NH}_{4} \mathrm{Cl}$ & 1600 & 13.30 & 8.48 \\
\hline
\end{tabular}

included $0.21 \mathrm{mg} \mathrm{ZnCl}, 0.2 \mathrm{mg} \mathrm{CoCl} \cdot 6 \mathrm{H}_{2} \mathrm{O}, 0.09 \mathrm{mg}$ $\left(\mathrm{NH}_{4}\right)_{6} \mathrm{Mo}_{7} \mathrm{O}_{24} \cdot 4 \mathrm{H}_{2} \mathrm{O}$ and $0.2 \mathrm{mg} \mathrm{CuSO}{ }_{4} \cdot 5 \mathrm{H}_{2} \mathrm{O}$ per liter. The vitamin solution included $0.1 \mathrm{mg}$ thymine, $0.1 \mathrm{mg}$ cyanocobalamin and $0.002 \mathrm{mg}$ biotin per liter.

Photobioreactor : A schematic diagram of the photobioreactors used in these batch experiments is shown in Fig. 1. All treatments were triplicated. Each reactor was constructed from a glass column with an internal diameter of $6 \mathrm{~cm}$, a height of $53 \mathrm{~cm}$ and an effective volume of $1.4 \mathrm{I}$. The column reactor was capped with a silicone valve and a glass tube was inserted, which served as an air inlet, as well as outlets to obtain samples and exchange air and water vapor. The air- $\mathrm{CO}_{2}$ mixture was bubbled at the bottom of the column reactors through a $0.22 \mu \mathrm{m}$ filter (SLFG05010, Merck Millipore, USA). The $\mathrm{CO}_{2}$ concentration was $1.0-2.0 \%$, while the gas flow rate was maintained at $0.2 \mathrm{I} \mathrm{min}^{-1}$. All column reactors were placed in a temperature-controlled water bath at $25^{\circ} \mathrm{C}$. The reactors were illuminated by $300 \mu \mathrm{mol} \mathrm{m}^{-2} \mathrm{~s}^{-1}$ with eight fluorescents in $12 \mathrm{hr}: 12 \mathrm{hr}$ light:dark cycle.

Inoculum preparation : The modified Walne's medium was sterilized in an autoclave for $20 \mathrm{~min}$ at $121^{\circ} \mathrm{C}$, then it was poured into a sterilized column reactor under aseptic conditions. Indigenous marine microalga $C$. vulgaris were cultivated in 1.4 I column reactors under an illumination of $300 \mu \mathrm{mol} \mathrm{m}^{-2} \mathrm{~s}^{-1}$ in a 12 $\mathrm{hr}: 12 \mathrm{hr}$ light:dark cycle for the pre culture. Illumination was measured with a light meter (LI-250A, LI-COR, USA). The culture was aerated with $1.0-2.0 \% \mathrm{CO}_{2}$ at $25^{\circ} \mathrm{C}$, and the gas flow rate was maintained at $0.2 \mathrm{~L} \mathrm{~min}^{-1}$. Algal cultures in the mid exponential growth phase were used as inoculum for the batch experiments.

Experimental setup : For the batch experiments, $C$. vulgaris was cultured with increasing ammonia concentrations, one at a high $\mathrm{pH}$ and high ammonia level and one nitrate level as shown in Table 1. The culture started with $100 \mathrm{mg}-\mathrm{N} \mathrm{I}^{-1}$ sodium nitrate and pH 8.0 was used as control. For experimental cultures, the nitrogen source of the modified Walne's medium was changed to ammonium chloride with different concentrations of 320, 640, 960

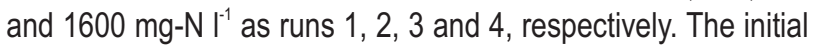
concentrations of free ammonia were $0.64,1.28,1.80$ and 2.97 $\mathrm{mM}$, respectively. Good's buffer (0.1 M Tricine) was used in all experiments.

Pre-cultured C. vulgaris was inoculated, and the initial biomass density was adjusted to $0.1 \mathrm{mg}-\mathrm{ds} \mathrm{I}^{-1}$. The column reactors were exposed to an irradiance of $300 \mu \mathrm{mol} \mathrm{m}^{-2} \mathrm{~s}^{-1}$ on a 12 hr: $12 \mathrm{hr}$ light-dark cycle at $25^{\circ} \mathrm{C}$. Each culture was aerated with $1.0-2.0 \% \mathrm{CO}_{2}$, and the gas flow rate was maintained at $0.21 \mathrm{~min}^{-1}$. Batch cultivations were continued until the biomass density became saturated.

After finishing cultivations of control and run 1 to 4 , an additional experiment was carried out with an ammonium

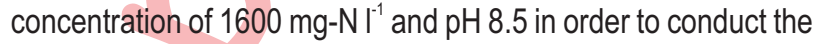
highest free ammonia condition of $13.30 \mathrm{mM}$ as run 5 .

Analytical methods : The $\mathrm{pH}$ of the samples was measured daily with a pH meter (B-712, HORIBA, Japan), and optical density (OD) was measured using a spectrophotometer (LAMBDA 25, PerkinElmer, USA) at $680 \mathrm{~nm}\left(\mathrm{OD}_{680}\right)$. Samples were filtered with a Whatman GF/A filter that was dried at $68{ }^{\circ} \mathrm{C}$ for $24 \mathrm{hr}$ and subsequently, cooled to room temperature in a desiccator for measurements of dry weight (DW).

To convert $\mathrm{OD}_{680}$ to $\mathrm{DW}$, the relationship between $\mathrm{OD}_{680}$ and DW obtained in a preliminary test using the following equations:

$$
\mathrm{DW}\left(\mathrm{g} \text {-ds l-1) }=0.1294 \mathrm{OD}_{680} \quad, \mathrm{R}^{2}=0.9941\right.
$$

Area productivity $\left(\mathrm{g}-\mathrm{ds} \mathrm{m}^{-2} \mathrm{~d}^{-1}\right)$ was calculated based on the biomass density measurements as:

$$
\text { Area productivity }=\left(D W_{n}-D W_{n-1}\right)^{*} V_{n-1} / A_{n-1}
$$

where, $D W_{n}$ is the $D W$ on day $n$ of batch experiments $\left(g-d s l^{-1}\right), V_{n-1}$ is the culture volume on day $n-1(I)$ and $A_{n-1}$ is the illuminated surface area on day $\mathrm{n}-1\left(\mathrm{~m}^{2}\right)$. In order to evaluate free ammonia tolerance of $C$. vulgaris, $V / N_{\text {max }}$ were calculated in which $V$ was area productivity of each experiments on day 1 and $V_{\text {max }}$ was the maximum area productivity of $15.13 \mathrm{~g}$ - $\mathrm{ds} \mathrm{m}^{-2} \mathrm{~d}^{-1}$ which was the maximum value in all experiments on day 1 .

Concentrations of total ammonia in each culture were measured using a colorimetric method (APHA, 2005). To estimate free ammonia concentration, the ratio of free ammonia to total ammonia $\left(\mathrm{NH}_{3} ; \%\right)$ was calculated by the following equation:

$$
\mathrm{NH}_{3}(\%)=100 /\left(1+[\mathrm{H}+] / K_{a}\right)
$$


where, $K_{a}$ is the dissociation constant of ammonia, $4.36 \times 10^{-10}$ at $25^{\circ} \mathrm{C}$ and $35 \mathrm{PSU}$ (Khoo et al., 1977). All the results were statistically calculated using R(Ver. R-3.4.2, New Zealand).

\section{Results and Discussion}

The dry weight of $C$. vulgaris increased in all batch experiments and reached around $4 \mathrm{~g}$-ds $\mathrm{I}^{-1}$, except run 5 at the end of the cultivation (Fig. 2). Although the initial ammonium

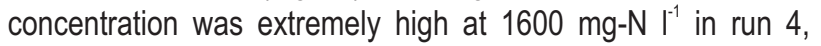
surprisingly, the cell density increased as well as the condition, which had lower concentration of ammonium. In runs 1 to 4 , the increase of cell density started immediately after beginning the experiments and showed a higher growth rate than the control, where nitrate was used as the nitrogen source. Most microalgae convert nitrate ion to ammonium ion inside the algal cell, which requires energy before amino acid synthesis (Podevin et al., 2015). Thus, the reason for the lower growth of $C$. vulgaris when nitrate was present is possibly due to additional intracellular processes to convert nitrate ions into ammonium ions. Indeed, higher growth rates were observed during runs 1 to 4 when ammonia nitrogen was used which could be direclty assimilated. In addition, the dry weights in run 1 to 4 finally increased to substantially high concentrations of $4 \mathrm{~g}$-ds $\mathrm{I}^{-1}$. This result indicates that $C$. vulgaris grew without growth inhibitions, even under high

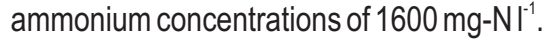

This finding led to an additional experiment (run 5), in order to investigate the growth of $\mathrm{C}$. vulgaris at higher free ammonia concentrations by increasing the $\mathrm{pH}$ condition. The cell density during run 5 was lower than those in runs 1 to 4 and was similar to the growth trend in the control at the beginning of cultivation. Although runs 4 and 5 contained the same ammonium

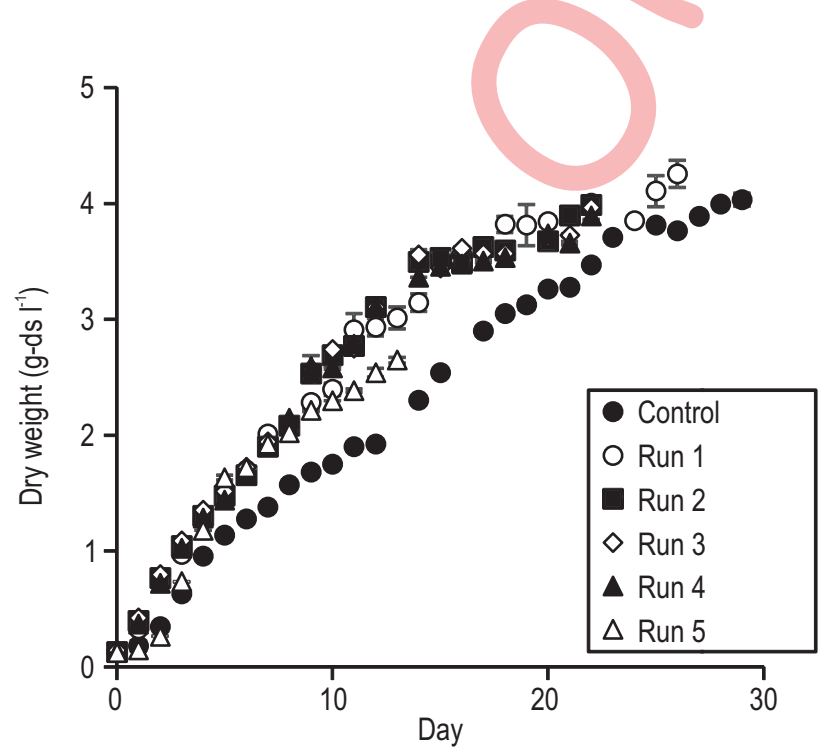

Fig. 2 : Growth curves of Chlorella vulgaris under different nitrogen conditions concentration, the cell density in run 5 was clearly lower than that in run 4 at the early stage of culture. At the elevated $\mathrm{pH}$ condition, the initial free ammonia concentration in run 5 was $13.30 \mathrm{mM}$, which was four times higher than that in run 4 . Thus, it seems that the growth of $C$. vulgaris was inhibited because of high free ammonia concentration in run 5 . After day 2 , the cell density in run 5 increased rapidly and reached the same value as the other experiments on day 5 . The $\mathrm{pH}$ slightly decreased during the experiment even though the culture media contained a $\mathrm{pH}$ buffer. This increase to the cell density was probably due to the decrement of free ammonia concentrations from $13.30 \mathrm{mM}$ to $3.66 \mathrm{mM}$ along with $\mathrm{pH}$ decreasing from 8.48 at day 0 to 7.88 at day 3. This result implies that the limit of free ammonia concentration that marine C. vulgaris can grow is around $3.7 \mathrm{mM}$.

Two different trends of area productivity were observed between runs 1 to 4 and the control and run 5 (Fig. 3). Area productivities during runs 1 to 4 was maximum around $15 \mathrm{~g}$-ds m ${ }^{-2}$ $\mathrm{d}^{-1}$ on day 1 and gradually reduced as time proceeded. Due to high productivities at the beginning, the cell density rapidly increased and reached a high value of $2.0 \mathrm{~g}^{-d s} \mathrm{I}^{-1}$ on day 7 (Fig. 2). The decrease of area productivity suggests a decrease in light energy and/or lack of nutrients due to high cell density at early stage of runs 1 to 4 . Meanwhile, area productivity in run 5 was low at around $4 \mathrm{~g}$-ds $\mathrm{m}^{-2} \mathrm{~d}^{-1}$ at day 1 and then increased to a maximum of $21.12 \mathrm{~g}$-ds $\mathrm{m}^{-2} \mathrm{~d}^{-1}$ at day 4 , which was the highest value in all experiments. Then, it decreased to $6.12 \mathrm{~g}$-ds $\mathrm{m}^{-2} \mathrm{~d}^{-1}$ at day 7 . The control showed a similar trend to run 5 , except the maximum value. The maximum area productivity in the control was $12.20 \mathrm{~g}$ ds $\mathrm{m}^{-2} \mathrm{~d}^{-1}$, which was the lowest of all experiments. This implies that the growth of $C$. vulgaris was inhibited by high concentrations of free ammonia at the beginning of cultivation in run 5 , however the area productivity rapidly recovered as time proceeded.

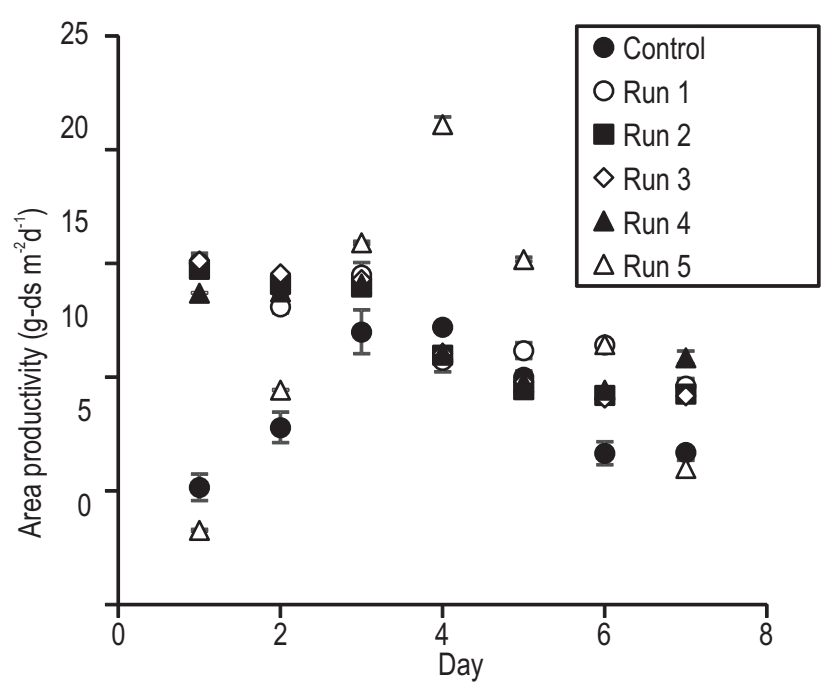

Fig. 3 : Area productivities of Chlorella vulgaris under different nitrogen conditions 
Table 2 : Effects of free ammonia concentrations to different microalgae species

\begin{tabular}{|c|c|c|c|c|}
\hline Species & Parameter & Calculated $\mathrm{NH}_{3}(\mathrm{mM})$ & $\mathrm{V} / \mathrm{V}_{\max }$ & Reference \\
\hline Scenedesmus obliquus & ${ }^{14} \mathrm{Cuptake}^{* 1}\left(\mathrm{mg}-\mathrm{Cl}^{-1}\right)$ & $\begin{array}{l}0.40 \\
1.00 \\
2.27\end{array}$ & $\begin{array}{l}1.00 \\
0.59 \\
0.03\end{array}$ & Azov and Goldman (1982) \\
\hline Phaeodactylum tricornutum & ${ }^{14} \mathrm{C}$ uptake ${ }^{*^{1}}\left(\mathrm{mg}-\mathrm{Cl}^{-1}\right)$ & $\begin{array}{l}0.52 \\
1.06 \\
2.72\end{array}$ & $\begin{array}{l}0.93 \\
0.69 \\
0.12\end{array}$ & Azov and Goldman (1982) \\
\hline Dunaliella tertiolecta & ${ }^{14} \mathrm{C}$ uptake ${ }^{*^{1}}\left(\mathrm{mg}-\mathrm{Cl}^{-1}\right)$ & $\begin{array}{l}0.62 \\
1.25 \\
2.51\end{array}$ & $\begin{array}{l}0.99 \\
0.59 \\
0.05\end{array}$ & Azov and Goldman (1982) \\
\hline Chlorella pyrenoidosa & $\begin{array}{l}\text { Mean Productivity }{ }^{* 2} \\
\left(\mathrm{~g} \mathrm{~m}^{-3} \mathrm{~d}^{-1}\right)\end{array}$ & $\begin{array}{l}1.41 \\
3.05 \\
5.26\end{array}$ & $\begin{array}{l}0.85 \\
0.46 \\
0.16\end{array}$ & Ten et al. (2016) \\
\hline Chlorella vulgaris & $\begin{array}{l}\text { Area Productivity }{ }^{\star 3} \\
\left(\mathrm{~g} \mathrm{~m}^{-2} \mathrm{~d}^{-1}\right)\end{array}$ & $\begin{array}{l}0.64(\operatorname{Run} 1) \\
1.28(\operatorname{Run} 2) \\
1.80(\operatorname{Run} 3) \\
2.97(\operatorname{Run} 4) \\
13.30(\operatorname{Run} 5)\end{array}$ & $\begin{array}{l}0.99 \\
0.98 \\
1.00 \\
0.91 \\
0.22\end{array}$ & This study \\
\hline
\end{tabular}

${ }^{11}$ The ratio of ${ }^{14} \mathrm{C}$ uptake when various $\mathrm{NH}_{4} \mathrm{Cl}$ were added to ${ }^{14} \mathrm{C}$ uptake when $\mathrm{NH}_{4} \mathrm{Cl}$ was not added; ${ }^{2}$ The ratio of mean productivity under various $\mathrm{pH}$ conditions to mean productivity under $\mathrm{pH}$ 5.7-6.5, where free ammonia concentration was less than lower detection limit; ${ }^{{ }^{3}}$ The ratio of area productivity of each experiment on day 1 to the maximum value in all experiments on day 1

The effects of free ammonia concentration on algal growth are sometimes expressed as $V / N_{\text {max }}$ in previous studies, which are shown in Table 2. The $V N_{\text {max }}$ of $C$. vulgaris was almost 1.0 when an initial concentration of free ammonia was below 1.80 $\mathrm{mM}$, but this decreased to 0.91 and 0.15 when the free ammonia concentrations were 2.97 and $13.30 \mathrm{mM}$, respectively. Azov and Goldman (1982) reported that the $V / N_{\max }$ of Scenedesmus obliquus, Phaeodactylum tricornutum and Dunaliella tertiolecta were more than 0.90 when free ammonia concentrations were around $0.6 \mathrm{mM}$, but decreased to less than 0.12 when the concentrations were around $2.3 \mathrm{mM}$. Additionally, Tan et al. (2016) reported V/ $N_{\text {max }}$ of Chlorella pyrenoidosa to be 0.85 at 1.41 $\mathrm{mM}$ free ammonia and then decreased to 0.46 and 0.16 at 3.05 and $5.26 \mathrm{mM}$ free ammonia, respectively. The $V / N_{\text {max }}$ of $C$. vulgaris was high in free ammonia concentrations that were sufficent to decrease $\mathrm{V} / \mathrm{N}_{\text {max }}$ in other species, indicating $C$. vulgaris has a relativley high free ammonia tolerance than others. It has been reported that ammonium concentrations in wastewater

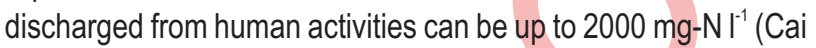
et al., 2013). Since, C. vulgaris was able to grow even at nearly the highest ammonium concentration in this study, this strain could be used in wastewater containing various ammonium concentrations, if free ammonia concentration could be maintained under $3.7 \mathrm{mM}$ by controlling $\mathrm{pH}$.

In this study, C. vulgaris had quite high tolerance for free ammonia concentrations compared to species reported in other studies because they were able to grow even under high free ammonia conditions of around $3.7 \mathrm{mM}$. In addition, it was clarified that $C$. vulgaris could grow well in high ammonium concentration of $1600 \mathrm{mg}-\mathrm{N} \mathrm{I}^{-1}$. Therefore, wastewater with extremely high ammonium concentrations could be used for ammonia removal and biomass production of $\mathrm{C}$. vulgaris if the free ammonia ratio is controlled by adjusting $\mathrm{pH}$ conditions, such as $\mathrm{CO}_{2}$ additions.

\section{Acknowledgments}

This research was supported by the Japan Science and Technology Agency (JST)/Japan International Cooperation Agency (JICA) through their Science and Technology Research Partnership for Sustainable Development (SATREPS) program and matching funds from the Ministry of Higher Education (MOHE) Malaysia in 2016.

\section{References}

APHA: Standard methods for examination of water and wastewater. $21^{\text {st }}$ Edn., APHA, AWWA, WEF, Washington DC, USA(2005).

Azov, Y. and J.C. Goldman: Free ammonia inhibition of algal photosynthesis in intensive cultures. Appl. Environ. Microbiol., 43, 735-739 (1982).

Cai, T., S.Y. Park, R. Racharaks and Y. Li: Cultivation of Nannochloropsis salina using anaerobic digestion effluent as a nutrient source for biofuel production. Appl. Energy, 108, 486-492 (2013).

Crofts, A.R.: Uptake of ammonium ion by chloroplast, and the mechanism of amine uncoupling. Biochem. Biophys. Res. Commun., 24, 127-133 (1966).

de la Noüe, J., G. Laliberté and D. Proulx:Algae and waste water. J. Appl. Phycol., 4, 247-254 (1992).

Khoo, K.H., C.H. Culberson and R.G. Bates: Thermodynamics of the dissociation of ammonium ion in seawater from 5 to $40^{\circ} \mathrm{C}$. J. Solut. 
Chem., 6, 281-290 (1977).

Perez-Garcia, O., F.M.E. Escalante, L.E. de-Bashan and Y. Bashan: Heterotrophic cultures of microalgae: Metabolism and potential products. WaterRes., 45, 11-36 (2011).

Podevin, M., D.D. Francisci, S.L. Holdt and I. Angelidaki: Effect of nitrogen source and acclimatization on specific growth rates of microalgae determined by a high-throughput in vivo microplate autofluorescence method. J. Appl. Phycol., 27, 1415-1423 (2015).

Rodolfi, L., G.C. Zittelli, N. Bassi, G. Padovani, N. Biondi, G. Bonini and M.R. Tredici: Microalgae for oil: Strain selection, induction of lipid synthesis and outdoor mass cultivation in a low-cost photobioreactor. Biothechnol. Bioeng., 102, 100-112 (2009).

Sepúlveda, C., F.G. Acién, C. Gómez, N. Jiménez-Ruíz, C. Riquelme and E. Molina-Grima: Utilization of centrate for the production of the marine microalgae Nannochloropsis gaditana. Algal Res., 9, 107$116(2015)$.

Sialve, B., N. Bernet and O. Bernard: Anaerobic digestion of microalgae as a necessary step to make microalgal biodiesel sustainable. Biotechnol. Adv., 27, 409-416 (2009).

Tan, X., Y. Zhang, L. Yang, H. Chu and J. Guo: Outdoor cultures of Chlorella pyrenoidosa in the effluent of anaerobically digested activated sludge: The effects of $\mathrm{pH}$ and free ammonia. Bioresour. Technol., 200, 606-615 (2016).

Walne, P.R.: Studies on food value of nineteen genera of algae to juvenile bivalves of the genera Ostrea, Crassostrea, Mercenaria and Mytilus. Fish. Invest. Lond. Ser. 2, 26, 1-62 (1970).

Yuan, X., A. Kumar, A.K. Sahu and S.J. Ergas: Impact of ammonia concentration on Spirulina platensis growth in an airlift photobioreactor. Bioresour. Technol., 102, 3214-3219(2011).
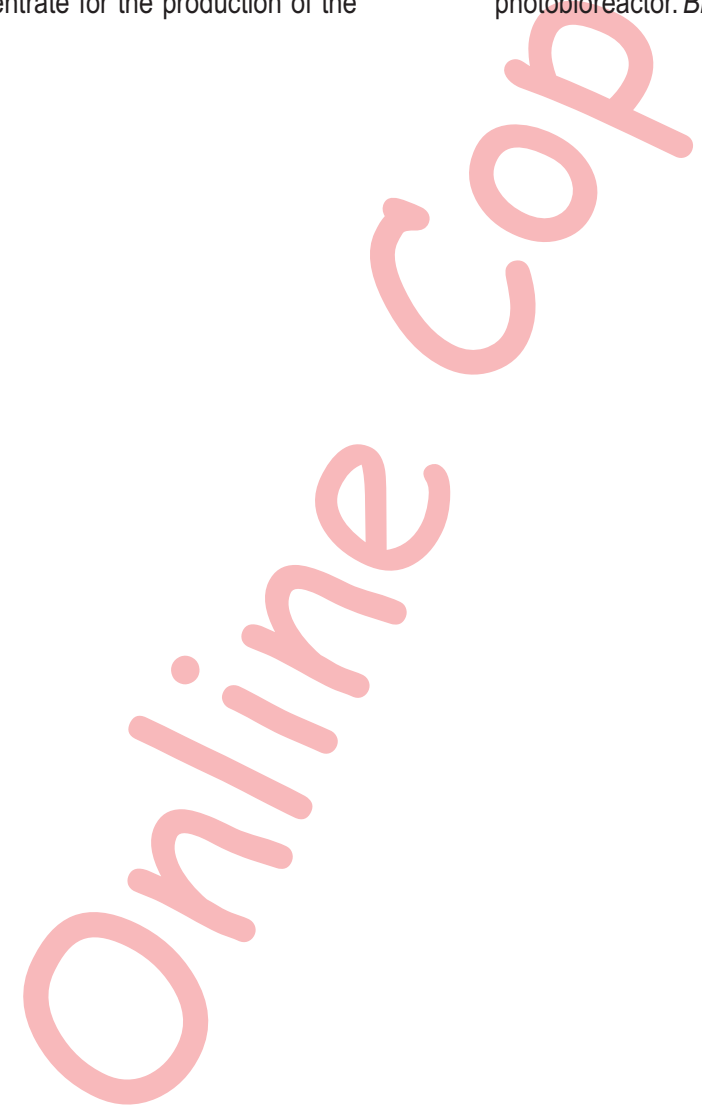